\title{
Urdimento
}

Revista de Estudos em Artes Cênicas E-ISSN: 2358.6958

\section{Um diário para as emoções: processo de educação pela arte com jovens privados de liberdade em Loja/Equador}

Carla Marcelino

\section{Para citar este artigo:}

MARCELINO. Carla. Um diário para as emoções: processo de educação pela arte com jovens privados de liberdade em Loja/Equador. Urdimento, Florianópolis, v. 3, n. 39, nov./dez. 2020. 
Um diário para as emoções: processo de educação pela arte com jovens privados de liberdade em Loja/Equador

Carla Marcelino ${ }^{1}$

\begin{abstract}
Resumo
Este artigo pretende refletir sobre uma experiência vivenciada no Centro de Adolescentes em Conflito com a Lei CAC, na cidade de Loja, Equador, por meio da introdução da linguagem da educação artística como abertura para o desenvolvimento de uma postura reflexiva sobre as emoções e a consciência existencial para o teatro. A partir das artes visuais e das artes cênicas, foi proposta a construção de um diário descritivo e estético, que foi preenchido a partir do estímulo de temáticas emocionais exploradas num sentido progressivo. Desde a pintura do autorretrato até os jogos e a dramatização de pequenos contextos, o registro feito foi abordado como metáforas a serem exploradas conversando, neste compêndio, com autores que respaldam o tema por meio da responsabilidade social da educação para a arte.
\end{abstract}

Palavras-chave: Educação artística. Emoções. Jovens infratores. Teatro e prisão. Sócio educativo.

\title{
Emotion diary: an artistic education process with private liberty youth in Loja / Ecuador
}

\begin{abstract}
Abastract
This article reflects on a lived experience in the Center for Adolescents in Conflict with the CAC Law, in the city of Loja, Ecuador. The article uses the language of artistic education as an opening for the development of a reflective posture about emotions and existential awareness in the theater. Drawig on the visual arts and the performing arts, a descriptive and aesthetic diary was composed, full of emotional themes explored in a progressive sense. From the painting of the self-portrait to the games and the dramatization of small contexts, the diary recorded works of artistic practice as metaphors that were meant to be explored in conversation with artists and writers who address the social responsibility of artistic education.
\end{abstract}

Keywords: Art education. Emotions. Young offenders. Theater and prison. Educacional Partner.

Gestora Cultural e Diretora Cénica com experiência na área artística, pedagógica, humanística e de investigação em indústrias criativas. Habilidades de gestão de processos humanísticos; comunicação e relacionamento; criatividade narrativa e expressiva; resolução de conflitos; liderança; escritura literária; curadoria e investigação cultural. csgarcia4@utpl.edu.ec 
Un diario para las emociones: un proceso de educación artística con jóvenes privados de libertad en Loja / Ecuador

\section{Resumen}

Este artículo pretende reflexionar sobre una experiencia vivida en el Centro de Adolescentes en Conflicto con la Ley CAC, en la ciudad de Loja, Ecuador, introduciendo el lenguaje de la educación artística como una apertura para el desarrollo de una postura reflexiva, sobre las emociones y la conciencia existencial para el teatro. Desde las artes plásticas y el arte escénico, se propuso construir un diario descriptivo y estético, que se completó con la estimulación de temas emocionales explorados en sentido progresivo. Desde la pintura del autorretrato hasta los juegos y la dramatización de pequeños contextos, el registro realizado se abordó como metáforas a explorar hablando, en este compendio, con autores que apoyan la temática desde la responsabilidad y la educación para el arte.

Palabras clave: Educación artística. Emociones. Jóvenes infractores. Teatro y cárcel. Socio educativo. 


\section{Querido diário... um acordo}

Recebi em mãos uma impactante carta convite cujo peso extrapolava as gramas do papel. A carga pesada da discriminação e do preconceito jaziam nas entrelinhas do espaço que requisitava um trabalho de educação no âmbito cultural das artes cênicas. Jovens. Crimes. Grades. Oprimidos e opressores. Entre estes, os omissos, incluindo-me - os que nunca tiveram nenhuma relação direta com uma instituição carcerária, mas que tinham muitas teorias. E poucas eram sobre o poder da educação emocional para a mudança de vida desses seres humanos em construção.

Este pedido de ajuda, feito pela instituição carcerária CACL ${ }^{2}$ - Loja à fundação FEDES ${ }^{3}$ vinculada a UTPL ${ }^{4}$, nos mobilizou então a criação de uma estratégia pedagógica, justamente em meio a emergência sanitária do COVID-19. Com as atividades educativas suspensas, os responsáveis manifestaram preocupação pelo tempo ocioso dos jovens detentos, já que começavam a manifestar situações conflitivas e de apatia.

Desafio aceito pela equipe do Observatório Cultural UTPL ${ }^{5}$, sob minha coordenação, também integrantes do corpo docente do curso de Licenciatura em Artes Cênicas UTPL ${ }^{6}$, com um propósito de estreitar o vínculo institucional, para conquistar o espaço como um futuro ambiente de aprendizagem das práticas acadêmicas e de vinculação comunitária para os alunos do curso.

A princípio, por exigência do protocolo de segurança, apenas um docente teria acesso presencial. Posteriormente, outros de somariam durante o processo. Isso não ocorreu, porque a cidade se manteve entre semáforo vermelho e amarelo ${ }^{7}$

\footnotetext{
${ }^{2}$ Centro de adolescentes em conflito com a lei de Loja, Equador.

${ }^{3}$ Fundação para o desenvolvimento Empresarial e Social da UTPL (FEDES, 2020).

${ }^{4}$ Universidade Técnica Particular de Loja - Equador (UTPL,2020).

${ }^{5}$ https://investigacion.utpl.edu.ec/es/observatorios/obscult

${ }^{6}$ https://www.utpl.edu.ec/carreras/artesescenicas
}

${ }^{7}$ Referência de segurança protocolar em relação a pandemia e a circulação de pessoas. 
durantes os três meses registrados desse experimento, restringindo a circulação de pessoas. Então como pedagoga e mestra em direção teatral assumi sozinha uma das experiências de teatro educação mais significativas da minha vida.

Primeira provocação: escolher a melhor metodologia para desenvolver o trabalho. Elocubrações sobre o tema, no sentido de fortalecer a inclusão, e tudo que poderia estar associado a este conceito, de jovens em estado de privação de liberdade no retorno ao convício social, me pareceram uma possibilidade exitosa dentro do terreno da inclusão cultural, mas não só isso. Era preciso pensar tal estratégia de maneira articulada e interdisciplinar, o que me levou ao planejamento de uma prática teatral desde uma pedagogia cênica cujo compromisso primeiro era o trabalho com as emoções.

Dentro dessa perspectiva, o Teatro do Oprimido seria, para mim, o mais indicado porque conduz, por meio de suas múltiplas técnicas e jogos, à busca por um sentido de transformação da própria vida em que o relevante é aportar para uma leitura pessoal do contexto e não diretamente do problema pessoal. Sobre isso, Violante (1982, p.22) corrobora que "as causas da marginalidade não podem ser procuradas no mundo próximo do indivíduo, nos fatores pessoais e psicológicos, mas na estrutura social. Porque, na medida em que se toma a marginalidade por suas manifestações, perdem-se de vista suas raízes".

O próprio Teatro Fórum possibilita ressignificar experiências íntimas relendo seu contexto. Como aponta Santos (2016, p. 30) "o oprimido é objeto da narrativa alheia e é um grande passo quando ele passa a ser narrador da sua própria história”.

Mas o ser narrador da própria história, com vistas a suas raízes, pressupõe uma entrega e uma confiança que neste projeto ainda não existiam, além de uma predisposição dos jovens para o trabalho de exposição no campo físico e das ideias. Concilio (2008, p. 149), na sua experiência com teatro na prisão, diz que é preciso investir antes "na construção de um vínculo sincero entre os integrantes e

\footnotetext{
${ }^{8}$ O Teatro-Fórum, considerado uma das técnicas mais completas e elaboradas por Augusto Boal, no Teatro do Oprimido, nasceu na periferia de Lima, mas evoluiu na Europa. Uma consequente evolução da técnica da dramaturgia simultânea, que incita os espectadores a tomar consciência integrando o público presente que propõe a resolução da cena. (SESI, 2012, p. 29).
} 
o texto, entre os integrantes e a encenação, e no fim entre os integrantes e compromisso com o público”.

O que fazer então quando não existe nem integrantes atraídos à importância do trabalho, nem texto, nem cena, nem público e, muito menos, vínculo com compromisso? Com base nesta investigação prévia ao trabalho prático, sabendo que o T.O. era, na sequência, a melhor decisão metodológica, pensei em realizar um trabalho prévio com suporte da pedagogia das artes para o preparo da emoção cênica. A ideia era introduzir o pensar 'além de', a autoestima, o amor próprio, a existência, a coletividade, o auto perdão, a modulação da emoções básicas e expressão de sentimentos e ideias por meio das artes visuais e escrituras como preâmbulo das artes cênicas e pouco a pouco mesclá-las num processo de transição para futuras criações performáticas metafóricas.

Assim, o desenho, a pintura, a palavra escrita, o recorte e a colagem de imagens seriam explorados dentro de um diário. Uma dramaturgia pessoal revivendo (ou para muitos vivendo pela primeira vez) o encantamento dos primeiros anos da escola, ressignificando memórias afetivas. Essa dinâmica, dentro da reclusão, para Oliveira (2001, p. 40) "é dar um sentido pra vida intra e extramuro". Para mim era importante para ressignificar minha pratica pedagógica num nível de responsabilidade e comprometimento nunca experimentados antes.

O recurso diário para as emoções, seria, então o instrumento escolhido para preparar a intuição e a consciência, para recolher dados deste intramuro, fortalecendo a criatividade para o trabalho prático de teatro que viria. A metodologia utilizada neste início de experiência foi, com vistas à construção de um mapa mental de possibilidades, a utilização de discussões sobre vídeos de narrativas de histórias de vidas reais.

Os vídeos, estrategicamente escolhidos, destacaram perguntas relacionadas ao aspecto humano, social e afetivo, numa mirada conduzida pela pedagogia freiriana que "problematiza os educandos como seres no mundo e com o mundo, desafiados, conectados e críticos" (Freire, 1987, p. 40). Neste processo de conquistar e captar os integrantes para o campo da arte propus um cronograma 
de atividades que presumia um encontro semanal de inspiração para registro diário, a princípio permanecendo no campo delimitado do secreto, do 'querido diário'.

Estimular as emoções e a diversidade de pensamentos, explorar a introspecção, a meditação, a autoanálise eram os pré-requisitos que almejava desta introdução à emoção cênica, porque o teatro, sempre ponderei, está antes do palco. Antes do texto. Está na "vida interior do espírito humano; na sua intuição e no seu inconsciente" (Stanislavski, 2009, p. 27). Por isso considerei muito importante esse cuidado pedagógico na introdução da arte como ferramenta de exprimir a vida, ainda mais quando se trata de adolescentes em processo de formação integral.

Na sua natureza democrática, a arte é, antes de ser arte propriamente dita, pensamento simbólico, intenção metafórica, abstrata e representativa. É gérmen sensível que purga, processo natural da ferida aberta antes da cicatrização. Totalmente envolvida com a proposta considerei este trabalho, como Oliveira (2001, p40), um viés para o "delinquente juvenil como um adolescente desalojado que busca de forma exacerbada um atalho de reconhecimento" encontrando o lugar/espaço esquecido ou perdido dentro de si, que os prepararia para um nível maior de entrega do trabalho que sugeriria.

\section{Querido diário... A chegada}

Forte entusiasmo tomou conta do planejamento. Da investigação teórica à seleção de recursos materiais, Piaget e Vygotsky também somavam pontos na minha revisão mental da prática pedagógica já que ambos, sociointeracionistas, “apontam que o conhecimento é construído por cada sujeito e não é o resultado de respostas adquiridas." (Nuño, 2018).

Assim, enfatizando a importância social da aprendizagem, mas pensando possiblidades de construções individuais, planificava, me assumindo mediadora deste processo de constituição de novos saberes, alguns de detalhes como: o tom da fala, o modo curioso de abordar um problema, a doçura em apontar uma 
reflexão e resgatar memórias sem influenciar diretamente no pensamento crítico, a firmeza e distintas nuances na oratória, ora suave e silenciosa como para ativar um suspense, ora grande e eloquente para chamar atenção.

Organizei cartinhas de boas-vindas, bolsas com kits artísticos e um diário. O 'querido diário' com a silhueta de um homem pássaro estampada sobre a frase "não existem metas impossíveis para aqueles que sempre demonstram força de vontade". Tudo personalizado. Com nome e sobrenome. Assim como Lage (apud Concílio 2008, p. 53) acreditava que "qualquer mudança começa no individual, para aí mudar o coletivo, o social”.

Hora da prática. Um resumo retrospectivo da minha visão da chegada: três guardas na entrada; uma guarita alta; alarmes; portões altos; cerca elétrica; muros enormes; um molho de chaves; revista pessoal; revisão do material; protocolo de higiene e desinfecção covidiana ${ }^{9}$; entrevista pessoal; uma janela/impressão (teria sido este espaço uma antiga escola?); agradecimentos; avisos prévios de segurança; deslocamento à sala.

Minutos eternos me levaram a encontrar 14 jovens entre 12 e 20 anos. Me cobriram olhares cheios de curiosidade, a princípio com uma certa reserva, que foi invadida por sorrisos logo da minha apresentação pessoal. Deu-se a entrega. O abrir-se para estar e viver com eles uma aventura emocional em forma de projeto deveria ser desde o início um acordo, um pacto de confiança mútua em que todos os lados saíssem ganhadores de experiências, sobretudo beneficiários do processo. Nesse panorama, igualmente como no T.O., "à estratégia é bilateral o que ensina aprende e o que aprende ensina." (Santos, 2016, p. 76) e aproveitando este ensinamento não perdi a oportunidade de dizer: "estou aqui para aprender com vocês".

${ }^{9}$ O projeto se desenvolveu em meio a emergência sanitária do vírus COVID-19, que requisitava protocolos de higiene e distanciamento. 


\section{Querido diário... 90 dias e alguns inesquecíveis registros}

Eu sou, eu estou. A primeira proposta que daria início a tantas outras fundamentais no processo do aflorar as emoções destes 90 dias, teria que ser muito estratégica para criar um vínculo emocional e demarcar o território da identidade. Foi então que explorei o tema da invisibilidade do setor carcerário e da incógnita: quem são as pessoas que estão ali? quem são vocês?

A proposta foi experimentar a escuta e incitar a reflexão crítica de uma narrativa ${ }^{10}$ real vivenciada, para criar argumentos estéticos que pudessem ser utilizados na atividade que era representar a si mesmo, como é e como está, cruzando enfoques de conceitos básicos que os levasse a pensar na constituição do eu (ser), pessoa e na condição do eu privado de liberdade (estar), situação. Condição esta muitas vezes indissociável, como expressada no registro de Jonas¹: "Queria mudar minha forma de ver a vida porque às vezes nada tem significado e me fecho num círculo onde eu penso que nunca vou sair".

Foi então que a primeira folha do diário recebeu estampada a cara/coração do artista/autor/ator dramaturgo da própria história. Mas, este desafio inicial encontrou como obstáculo um escasso desenvolvimento artístico estético.

10 Narração de Andrea Casamento, Argentina, cujo filho de 18 anos levado por engano para uma prisão de segurança máxima, foi sua porta de entrada neste mundo até então desconhecido levando-a a enfrentar um sistema judicial desumano. Seu olhar destaca que o que acontece na prisão, por mais distante que pareça, influencia diretamente a maneira como se vive com o problema da insegurança. Desde aí passou a questionar quem são estas pessoas e preside, atualmente, a Associação Familiar de Detidos em Prisões Federais (ACIFAD). (Casamento, 2017).

\footnotetext{
${ }^{11}$ Nome fictício para proteger a identidade.
} 


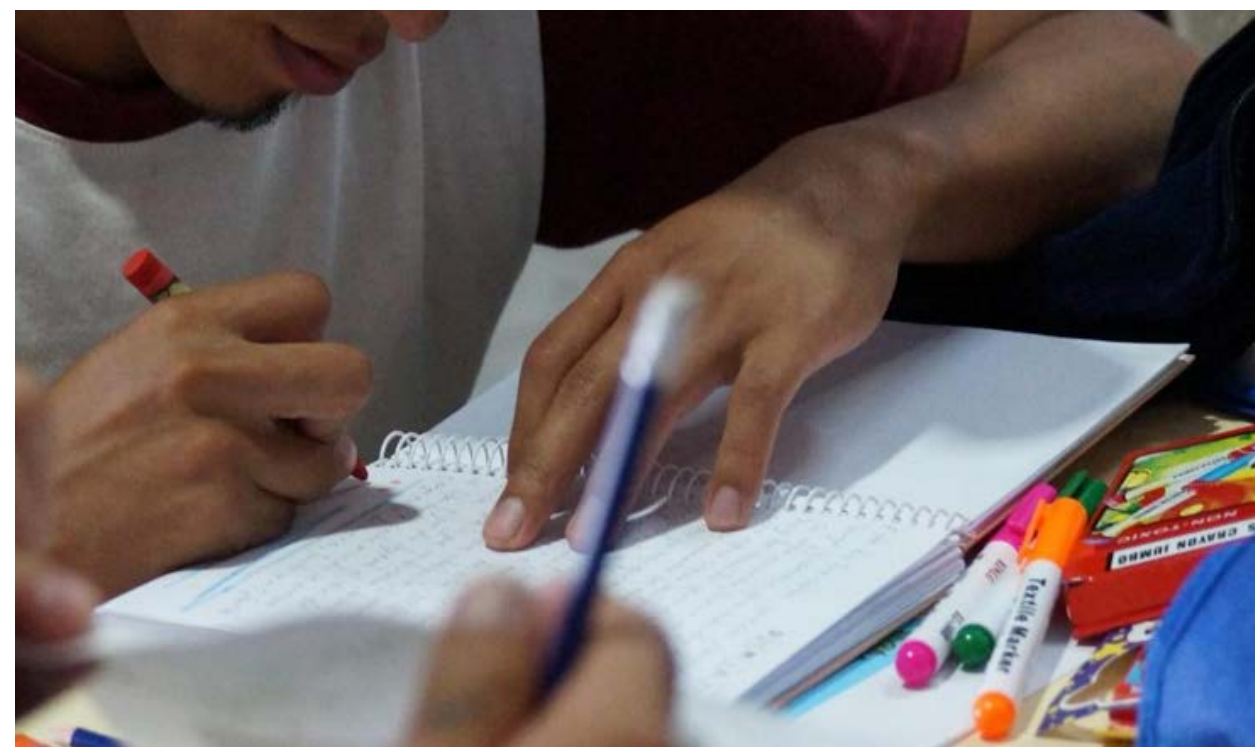

Fonte: Acervo investigativo de Carla Marcelino

Embora todos tivessem em mãos um kit de recursos materiais, poucos o utilizaram de maneira criativa, personalizada, explorativa. O sentimento sobressalente era o medo 'de ousar' em um processo onde a liberdade de expressão estava há muito adormecida.

Frente ao dilema, para adaptar e incluir a 'expressão', dei um passo atrás com base na reflexão de que não bastaria entregar recursos, seria necessário ensiná-los a utilizá-los partindo das habilidades pessoais de cada um. Evocando o mestre Boal (1998, p. 12) que nos pede para transformar o espectador, "ser passivo e depositário, em protagonista da ação dramática” preparando suas ideias para atuar no futuro sem se satisfazer com reflexões sobre o passado, porque "os analfabetos não são pessoas que não sabem se expressar: são simplesmente pessoas incapazes de se expressar numa língua determinada, imposta” (Boal, 2012, p. 14), incluí uma aula sobre como utilizar cada recurso: lápis de escrever, lápis de cor, tesoura e possibilidades de recortes, uso de imagens em revistas e jornais, aplicação da cola. Além disso: iconografia (símbolos, espaço, linhas, formas geométricas, simetria, assimetria, textura, etc.). Tudo que pudesse ampliar outras línguas não impostas a desenvolver uma comunicação. 
Assim, convidados a adentrar no mundo das metáforas, a descobrir novas linguagens não determinadas, fundamental para a Estética do Oprimido que sugere "exercitar o olhar interessado em desvendar os conteúdos impregnados na imagem observada para entender que uma representação é resultado da escolha de alguém para comunicar uma determinada perspectiva" (Santos, 2016, p. 54), aos poucos os rabiscos criaram significados que renderam discussões sobre visões de mundo, contextos e pontos de vista.

Figura 2 - Autorretrato meu SER, meu ESTAR - CAC Loja/2020

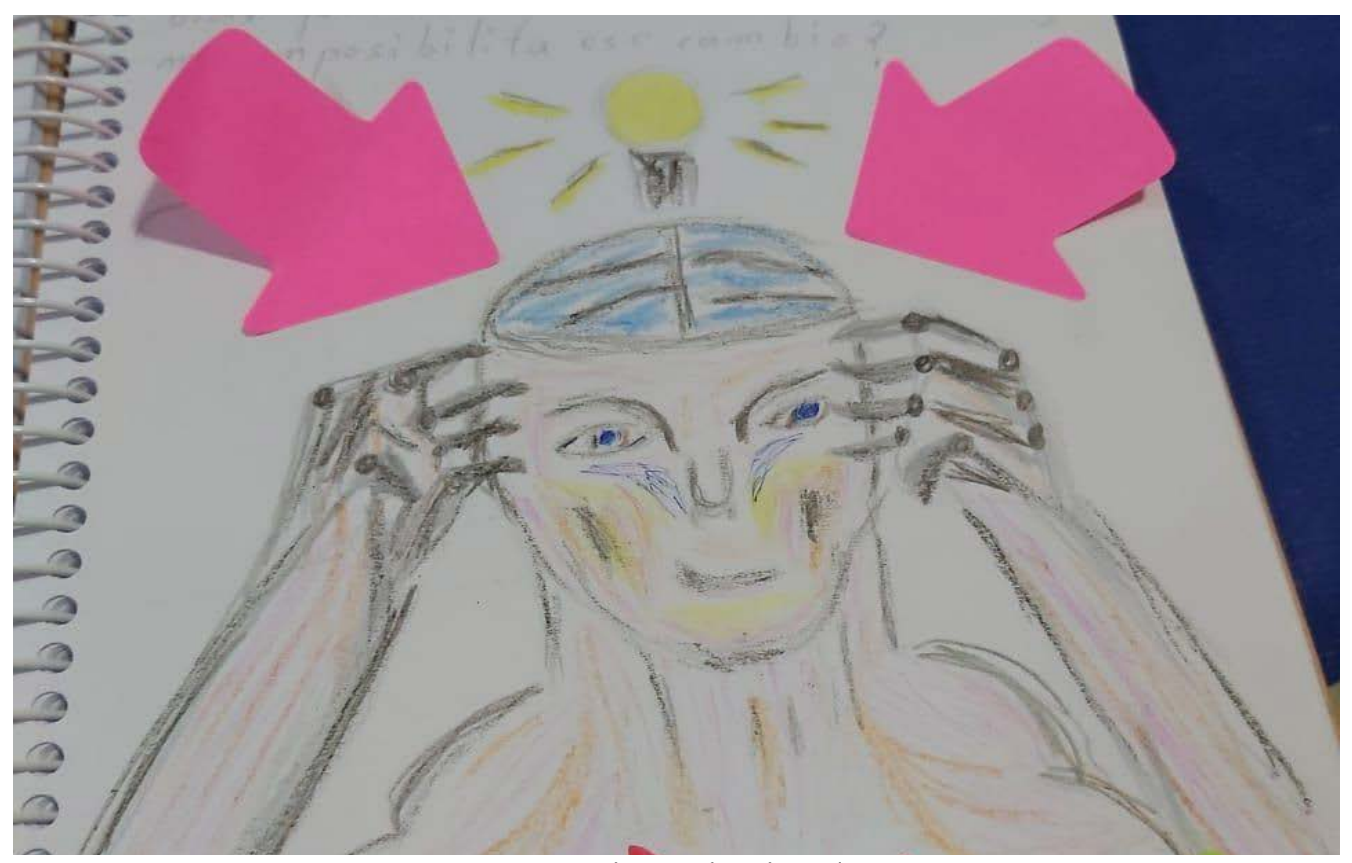

Fonte: Acervo investigativo da autora

Em outro momento, ao explorar o texto "Quando me amei de verdade" (McMillen, 2003, p.84), difundido por Chaplin, a colagem/ilustração foi cultivada como recurso argumentativo. Grandes histórias apareceram nos pequenos detalhes, muitas delas possíveis de ver na leitura estética de uma "encomenda"12 de imagens. Enquanto uns me pediam figurinhas de personagens orientais, outros pediram fotos de girassóis e pássaros; de um lado o suor dos times de futebol, de outro, fumaça de potentes máquinas de motocross. O Cristo do narcotráfico

${ }^{12}$ Foi pedida aos alunos uma lista de imagens para trabalhar uma criação artística e leitura reflexiva de perspectivas e expectativas pessoais. 
dividiu espaço com personalidades da Disney. Imagens de ursos ferozes se imprimiam na mesma folha de delicados animes. Falaram-me tanto, sem sequer se darem conta. E eu entusiasta, recebia com preocupação um novo cenário, porque tentava promover mais que um momento de aprendizagem, um momento de prazer, um eco de liberdade dentro da privação, uma relação de afeto que demonstrava interesse por aquelas histórias contadas de várias maneiras.

Dentro desta proposta de desenvolver uma emoção cênica por meio de um diário, a fala surgiu no trabalho estético com uma certa função digestiva na representação de fragmentos significativos daquelas histórias. E foi somente na quarta aula que dois deles se propuseram a falar oralmente em público.

A primeira saída do papel para o coletivo foi "eu tenho medo de falar, mas eu quero falar porque eu decidi que eu quero mudar a minha vida" (Artur ${ }^{13}$ ). Aqui a fala renova o sentido da vida, sobre isso concordo com Bárbara (2020, p. 283) quando ela insiste na força do debate para o enfrentamento de debilidades quando diz que "os temas, os mais difíceis não devem ser evitados nem silenciados, devem sim ser enfrentados”. E Boal (2000, p. 338) ressignifica ainda mais este sentido quando insiste no registro destas falas como instrumento de defesa social justificando que "é preciso brigar contra a rendição fatalista que se alastra como se não houvesse opção, escrevendo - palavras!"

Um dos registros deste instrumento, contra a rendição, encontra-se na figura 3, na qual as palavras simples e sinceras sobre um companheiro em relação ao outro reclamavam sobre "uma condenação muito injusta para quem é apenas uma criança ${ }^{14}$ e não entende de leis". Nota-se, portanto, que o ato de verbalizar estava relacionado a uma ação para além dos muros. Para um novo contexto. E foi exatamente nesse esperado momento que iniciei o processo de mesclar dinâmicas da arte cênica como apoio àquelas artes visuais antecessoras e registros descritivos no "querido diário".

\footnotetext{
${ }^{13}$ Nome fictício para proteger a identidade.

${ }^{14}$ Neste caso o menino acusado tem 12 anos de idade.
} 


\section{Querido diário... Que comecem os jogos}

Uma das primeiras atividades de transição entre a caneta e a cena foi o jogo de releitura de imagens. A obra escolhida por eles foi uma Santa Ceia, pintada na parede do refeitório. Estavam animados e testaram várias posições em frente as imagens, proporcionais aos seus tamanhos reais. Falavam sobre as características físicas retratadas dos personagens, se comparavam, algumas pareciam com a suas. Outros se concentravam na atitude corporal. Pude perceber um controle muito maior da ansiedade nesse início de atividade teatral comparado ao início das atividades de escrita no diário. Pareciam muito sensíveis a iniciativa fazendo o corpo esperar a hora do jogo, já que estar ali imitando aquelas figuras era uma espécie de jogo ou brincadeira.

E brincar para eles, percebi, ainda era muito divertido. Mais divertido que o compromisso de uma escrita. Sobre isso entendi o mesmo que Rodrigues (p. 38, 2019) quando afirmou, em meio a um processo do brincar também com seus alunos privados de liberdade, que "a "caixinha" de cada um se abriu em meio a sorrisos e brincadeiras; a máscara do criminoso deu lugar ao menino desprotegido e entregue ao faz de conta dos jogos. O faz de conta que sou o outro".

E foi assim, neste brincar como exercício de vida, que eles elegeram o personagem a reler individualmente e montaram, com seus corpos, a figura coletiva fazendo uma comparação com a pintura na parede, em silencio enquanto eu tirava várias fotos. Fato curioso, e que chamou minha atenção, foi o pós jogo, quando cada um me pediu fotos individuais na frente do painel. Muitas delas, impressas posteriormente, foram coladas nas folhas do diário como uma recordação daquele momento de prazer.

Este aspecto lúdico, canal direto de comunicação, ferramenta potente de distanciamento, pôde ser visto em vários outros momentos de jogos teatrais. Como na dinâmica da posse da cadeira ${ }^{15}$, por exemplo. Utilizada para introduzir o

15 Uma cadeira é colocada entre dois jogadores. Um deles estará sentado e fará de tudo para permanecer sentado e defender seu espaço. O outro estará ao redor da cadeira esperando uma oportunidade e elaborando estratégias para sentar e dominar o lugar do outro, tudo sem contato físico. 
tema oprimido e opressor, o desafio que eu até então não tinha percebido estava muito além da simples dinâmica de ocupar um espaço físico. Já existiam ali vários tipos de ocupações de espaços metafóricos nas relações de poder entre eles. Então, para alguns o jogo era uma ameaça, para outros uma oportunidade. Até então os trabalhos que estavam na zona introspectiva ganharam com o jogo da cadeira um novo suporte de comunicação, o corporal ativo, para dominar novos espaços naquele contexto que se tornava um espaço de liberdade, de permissão. Sem muita técnica o jogo proporcionava a experiência mais indicada para iniciação do teatro, que segundo Boal (1980, p.133) “deve começar pelo próprio corpo das pessoas interessadas em participar da experiência."

Nesta extroversão, "diálogos entre os corpos de diferentes indivíduos" (Boal, 2015, p.97) muitos olhares se cruzaram marcando claramente uma intimidação. Outras vezes, a cadeira era simplesmente cedida, no sinal que de, nem brincando, se poderia ocupar um espaço de alguém com mais poder, ainda que se soubesse como.

Movimentos criativos como espalmar a mão ou colocar um pé demarcando território sobre o assento arrancava gargalhadas e geravam novas discussões sobre sofrer ou fazer sofrer. Ao possibilitar a participação nas duas situações - o oprimido tentava sentar na cadeira e o opressor tentava impedi-lo -, percebi uma empatia instantânea, um colocar-se no lugar do outro. Impressões essas registradas, por eles, no diário. Reflexões para além dos muros, na tentativa de resolver algumas pendências alheias ${ }^{16}$.

Nesta altura do trabalho, ainda que custasse para muitos plasmar sentimentos numa folha de papel, testemunhei uma evolução da estética a partir do visual do diário e consequentemente uma abertura para falar de si mesmo.

Escritores, poetas, humoristas, religiosos, filósofos. Cada qual mostrou parte de sua visão de mundo na expressão da escrita. Enquanto para alguns o texto dolorido da preocupação familiar só poderia ser escrito com a tinta fria da caneta,

${ }^{16}$ Logo após a atividade, os alunos foram convidados a fazer o registro das impressões sobre o novo tema Oprimido X Opressor e se pode visualizar em muitos diários a palavra família. Alguns inclusive escreviam frases que remetiam a um pedido de perdão comportamental. Porque para muitos, ainda que ali naquele ambiente eles sejam os oprimidos, em suas casas ou círculos de confiança foram os opressores. 
para outros o lápis de cor serviu como recurso para ressaltar atitudes a serem alimentadas no seu processo de superação, como pode ser visto nos registros das figuras 8 e 9 .

Figura $3^{17}$

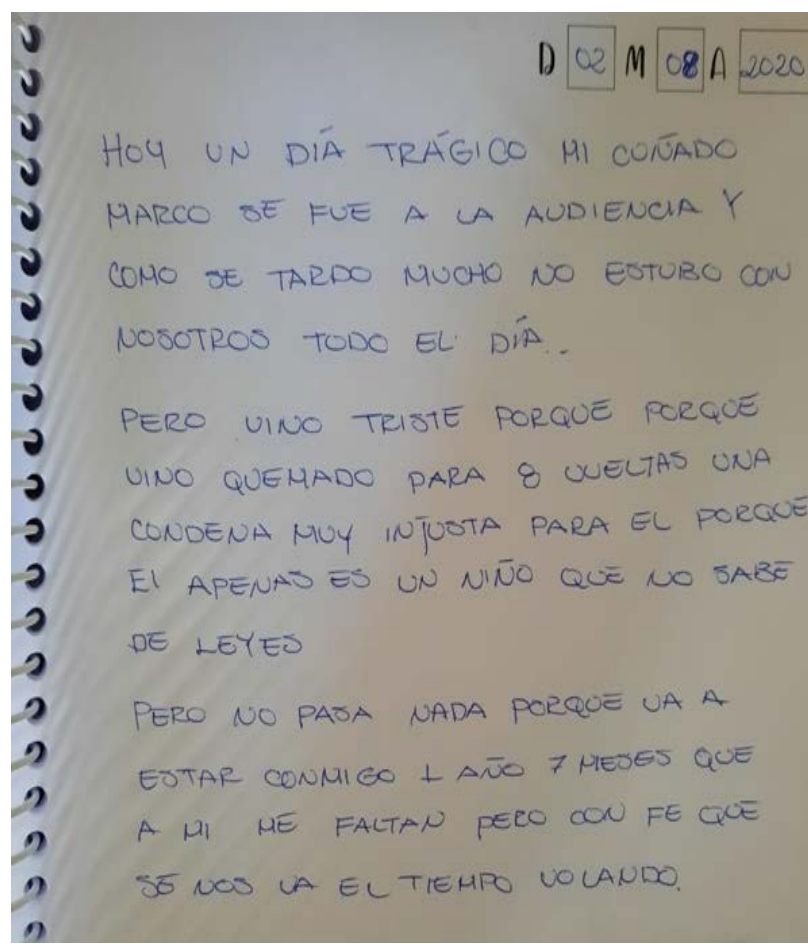

Figura $4^{18}$

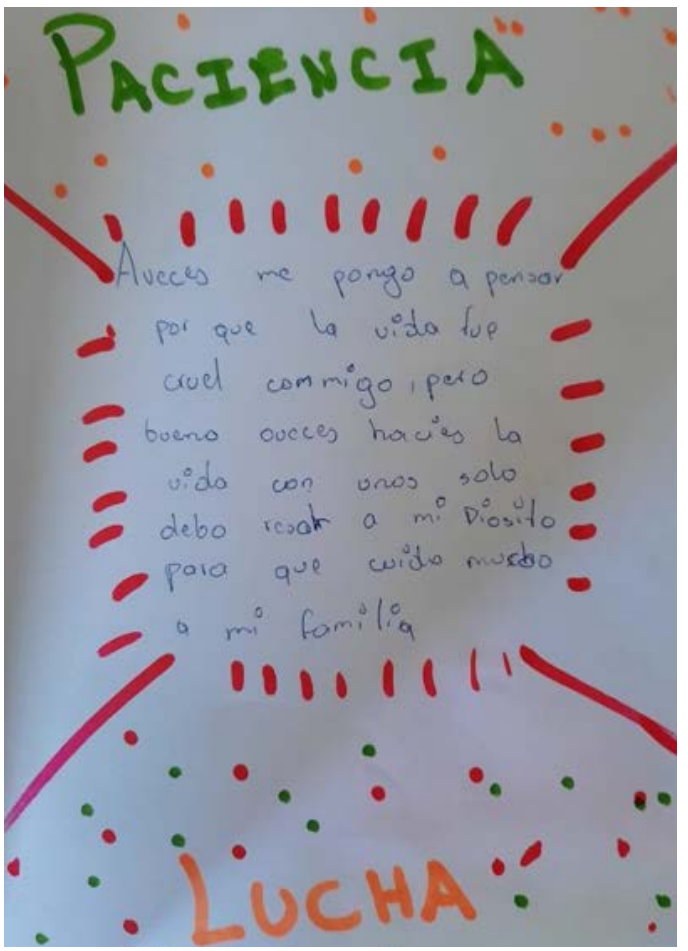

O diário como introdução do trabalho corporal serviu como antessala da entrega e da confiança, qualidades estas também exploradas com muita desenvoltura no jogo do 'ponto focal estratégico'. 19

${ }^{17}$ Registro de diário de um interno. Tradução: Hoje um dia trágico, meu cunhado Marco foi à audiência e como se atrasou não esteve conosco o dia inteiro. Voltou triste porque veio queimado com oito voltas. Uma condenação muito injusta para ele porque é apenas um menino e não entende nada de leis. Mas tudo bem, porque vai estar comigo por um ano e sete meses que é o que me falta. Com fé o tempo vai passar voando. Fonte: Acervo investigativo de Carla Marcelino.

18 Registro de diário de um interno. Tradução: Às vezes fico a pensar porque a vida foi cruel comigo. Mas às vezes penso que a vida é assim mesmo e que devo rezar para que Deus cuide da minha família. Paciência. Luta. Fonte: Acervo investigativo de Carla Marcelino.

19 Este jogo de improviso dispõe de 4 cadeiras localizadas nas extremidades de um grande quadrado imaginário, o tamanho deste quadrado varia de acordo as habilidades dos jogadores. Quanto maior, mais difícil. Quatro pessoas começam o jogo sentadas e uma quinta pessoa em pé, no meio do círculo. O objetivo é que os jogadores troquem de lugar sem mexer nas cadeiras e sem falar, apenas estabelecendo estratégias com olhares, para que o jogador do centro não as ocupe. Se o jogador do centro sentar em alguma cadeira, aquele que a pertencia passa a ser o do centro. 
Figura 5: Jogo do ponto focal estratégico - CAC/Loja

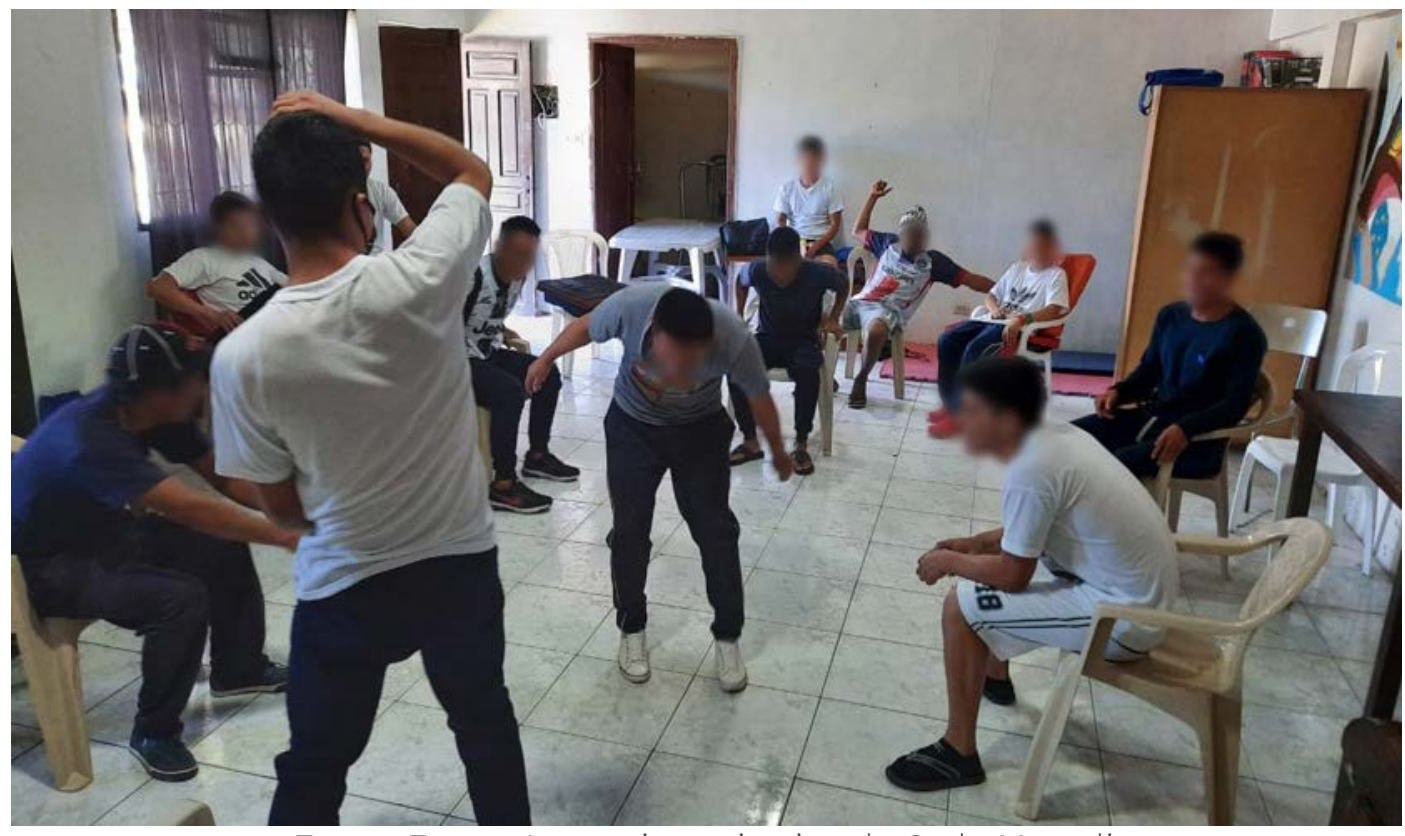

Fonte: Fonte: Acervo investigativo de Carla Marcelino

A princípio, o jogador que estava no centro sempre ocupava um lugar. Era pouca a interação entre os que estavam sentados. Olhavam, mas não viam. O olhar expressivo diz muito, diz do corpo e da alma. Então, a princípio, os olhares não eram muito sinceros e verdadeiros. Eram quase sempre deslocados para baixo, desviados para os lados, para as mãos, ou para mim, articuladora das regras. Eram olhares rápidos. Não pousavam muito tempo dentro de outros olhares.

Mas, a necessidade de 'ganhar' o jogo, ou pelo menos tentar sobreviver mais tempo nele, levou-os pouco a pouco a interagir visualmente. Fiz uma pausa para interpretar a situação e falar sobre o papel do olhar. De volta ao desafio o que se apresentou foi um verdadeiro descortinar de gentes. E prazeres. Prazer de realizar, de cumprir, de ser exitoso, mesmo que só sobrasse o lugar do centro. Brincando outra vez estavam existindo, ainda que sem liberdade.

"Você existe, mesmo que não tenha liberdade." Fala de Pablo Balo ${ }^{20}$ que reforça que a privação de liberdade não deveria cruzar o projeto existencial do ser humano, indica que tudo é passageiro, inclusive o processo. Por isso nada deveria

20 Ex-presidiário, passou vários anos na prisão de alta segurança em Ittre Bélgica (Tagu, 2017). 
impedir uma pessoa de melhorar-se fisicamente, psicologicamente, emocionalmente, enquanto espera. Pablo também afirma que "a vida diária de um privado de liberdade é reduzida à espera e de certa forma, por isso alguns perdem sua identidade." (Tagu, 2017).

Concordando, trabalhei com essa proposta múltipla, que explorou várias ferramentas artísticas a partir da expressão do pensar para possibilitar a eles moverem-se ao palco, como uma evolução interna, o que resultou efetivo, tanto que propiciou transformações verdadeiras. Encorajamentos e convites à mudança. Um ensaio de liberdade.

Em entrevista, a diretora do CACL, Silvia Naranjo, apontou que, desde que se iniciou o trabalho com os diários e posteriormente com os jogos teatrais, se percebeu uma mudança crescente no comportamento dos jovens em relação ao grupo. Empatia, solidariedade e encantamento se manifestavam com mais frequência e se convertiam em mecanismos retro alimentadores do próprio diário onde novas experiências, outras percepções do outro e de si mesmo, e um vocabulário mais ampliado eram assuntos plasmados nas folhas de papel, ainda que existissem exceções.

Embora eu presenciasse alguns olhares, pousados em face sem rugas, endurecidos e desprovidos de esperança, que colocavam em dúvida a própria eficácia da minha proposta, me fazia lembrar sempre que o projeto não tinha como objetivo a imposição, tudo se daria por meio da conquista, lenta e gradual, porque o tempo de despertar está totalmente vinculado com as experiências emocionais que os jogos teatrais também evocam. Para alguns era prazer. Para outros, dor.

Tais argumentos foram constatados e comparados entre dois jogos propostos. O Jogo do papo furado ${ }^{21}$, dinâmico e divertido e o Jogo da cadeira

${ }^{21}$ Este jogo se organiza com duas fileiras paralelas de igual número de jogadores, frente a frente, sentados cada um em uma cadeira. Quando o mediador dá comando TROCA, os jogadores da fileira A sempre vão se mover para a direita, ocupando a cadeira ao lado. E os jogadores fileira B sempre vão se mover para a esquerda, igualmente ocupando a cadeira ao lado. Quando o mediador dá o comando O TEMA É... cada jogador, já sentado na sua nova posição, deve olhar apenas para o jogador da sua frente, e somente com ele vai falar tudo que vier na sua cabeça sobre o tema proposto. Se permite 30 segundos de interação entre as duplas y novamente se dá o comando "troca", seguido de "o tema é", com um novo tema. 
performática ${ }^{22}$, introspectivo e sensível.

No jogo do papo furado, dentre os temas utilizados, o que mais estimulou a criatividade e a euforia dos jovens foi: 1. minha comida preferida é...; 2. as pessoas em quem eu mais confio são...; 3. se eu tivesse um milhão de dólares eu...; 4. quando eu sair daqui a primeira coisa que vou fazer é...; 5. os palavrões que eu sempre quis dizer em público são...; 6. me sinto lindo quando... Como todas as duplas falam ao mesmo tempo, rodiziando em cada tema, ocorre uma troca de contextos de maneira muito leve.

Eles falam de si, do seu mundo, dos seus gostos. E também escutam. Tudo sem a pressão de um moderador avaliando diretamente o que é dito. Muitas vezes o comando teve que ser repetido tamanha concentração pela brincadeira. Um brincar sério, cheio de dizeres, que também se transforma em matéria prima para a própria investigação dos temas do T.O. pois, ainda que muitas falas se relacionem com questões externas de modelos preconcebidos, nessas respostas sempre resgatava pistas valiosas da visão de mundo de cada um.

Diferente deste, o jogo da cadeira performática evoluiu de forma muito tensa. Para entrar no jogo, os alunos assistiram antes a um vídeo de Juan Pablo Gaviria ${ }^{23}$ sobre “O que é o medo?” (Gaviria, 2020). Na reflexão posterior, muitas bocas fechadas, cabeças baixas, olhares dispersos. Questionei sobre os medos, e a maioria dos medos citados eram em relação à morte ou abandono materno ou em relação a voltar aquele ambiente por fracassar outra vez no futuro.

Para afrontar com a descontração do jogo anterior, a ideia inicial deste jogo era usar o tema medo para propor analogias da relação de cada um com este

\footnotetext{
22 Este jogo propõe que cada jogador se coloque num determinado espaço da sala com uma cadeira. Eles devem andar ao redor da cadeira, manipulá-la e observá-la como um objeto artístico. Devem estimular a imaginação para pensar além do sentar. Ao som de uma música introspectiva, eles têm alguns minutos para experimentar movimentos diferentes utilizando este objeto. A seguir, devem definir cinco movimentos bem marcados. Dos cinco, devem escolher três e fixar um ritmo executando-os numa sequência. Depois de ensaiar bem os três movimentos ritmados numa sequência, se retira a cadeira e eles devem seguir ampliando bem o movimento corporal. A partir deste passo se pode criar muitas variações de acordo com o objetivo da aula.

${ }^{23}$ Coaching dedicado a compartilhar workshops, um dos principais expoentes do propósito de vida e felicidade na Colômbia, cujo objetivo é "usar a criatividade como uma ferramenta para inspirar compromissos de mudança nas pessoas e em seu ambiente." (Gaviria, 2020).
} 
sentimento por meio de metáforas corporais. Frente às primeiras reações de rejeição, a alternativa mais segura para não perder a confiança já adquirida seria mudar o foco inicial. Foi então que sugeri que a cadeira fosse explorada mecanicamente, apenas como objeto artístico.

Clima mais relaxado, todos participaram. Distintos movimentos foram criados. Pés, mãos, quadril, joelhos, cabeça exploraram o sentar, arrastar, girar, levantar, empurrar. Minha voz de comando sempre sugeria brincar com a imaginação - E se a cadeira fosse uma comida? Um carro? Um animal? Um inimigo? Um amigo? Um presente? Somados a um ritmo em uma sequência a criatividade foi surgindo.

Em seguida, eles deveriam escolher apenas três movimentos de todos os criados. Repetiram-no até memorizar. E o fizeram igualmente sem as cadeiras. Para muitos surtiu uma surpresa estar ali fazendo três movimentos sem o objeto de referência. Para outros pareceu engraçado. Foi então que solicitei incluir o tema medo como suporte dramatúrgico da brincadeira que se tornava uma performance.

Para terminar a atividade, pedi a eles que utilizassem essa criação corporal memorizada para dizer algo sobre o medo, ampliando ou diminuindo os movimentos, colocando força, violência, fragilidade ou curiosidade nas ações. Igualmente o ritmo agora poderia ser modificado porque o ritmo também poderia contar algo sobre o medo, atrasando ou acelerando, conforme o sentimento de cada um em relação ao que o mesmo medo the provocara. Resultou muito positivo e se obteve, então, um ensaio de uma primeira criação performática de T.O. do grupo do CACL. Reflexivos, eles sentaram pensativos nas suas mesas para escrever suas impressões no querido diário. E eu fiquei emocionada por presenciar aquela construção. 
Figura 6: Jogo da cadeira performática - CAC/Loja

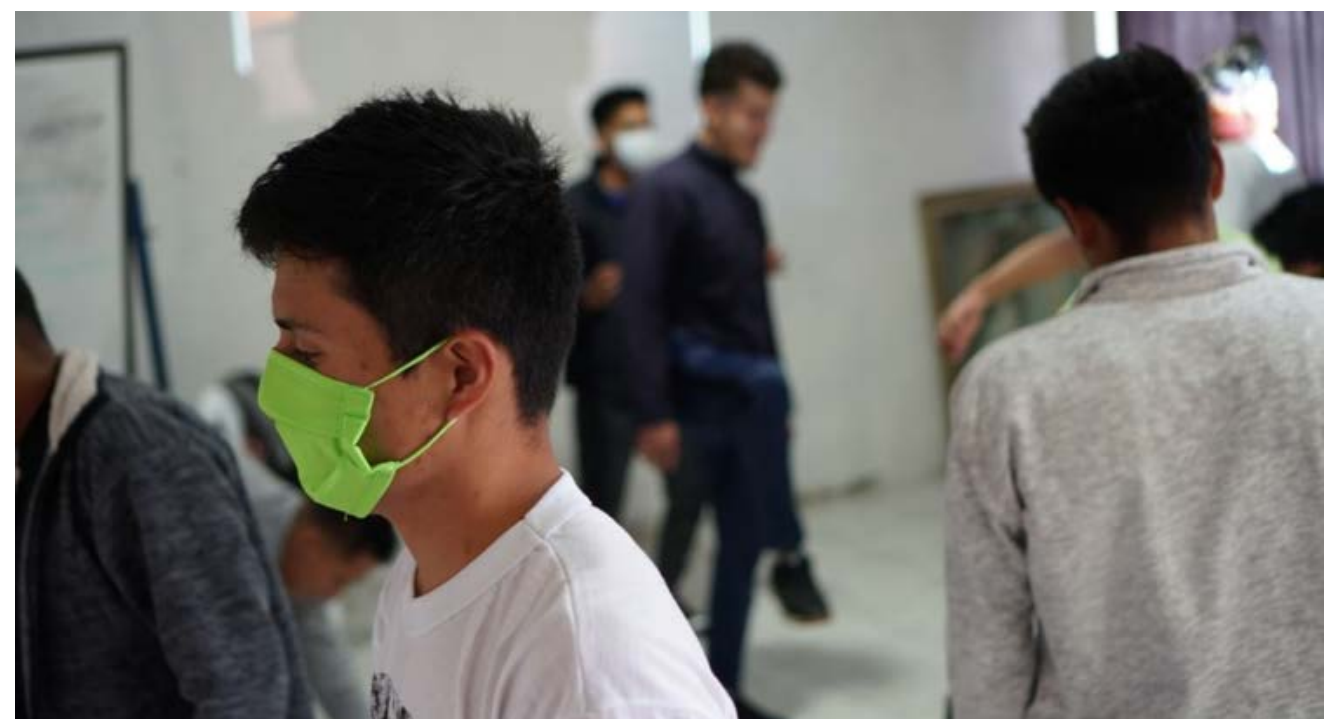

Fonte: Fonte: Acervo investigativo de Carla Marcelino

Em outra oportunidade, no Jogo do Rá24, o excesso de energia acumulada naqueles corpos resultou numa grande catarse. Anterior a este jogo, provoquei um exercício de escrita e reflexão sobre os temas "problemas" e "gratidão". A ideia era levá-los a pensar e repensar a imagem que concebiam sobre suas lutas, suas dores, mas também suas conquistas e suas alegrias. Nessa dinâmica, a palavra problema remeteu a duas grandes reflexões entre eles: o que os levou a estarem ali e o que enfrentariam ao sair dali. Ao parecer estar ali naquele momento não era, de maneira nenhuma, um problema.

O centro de privação de liberdade que abriga esses jovens tem uma preocupação com a formação deles, e o trabalho com teatro não era a única

${ }^{24}$ O Jogo do Rá requer atenção, coordenação motora e aceitação do ridículo. Em círculo, todos os envolvidos são distribuídos a uma distância de mais ou menos meio metro cada um. O moderador inicia o jogo com o movimento 1, de friccionar as mãos enviando para a pessoa que está ao seu lado uma energia. Esse movimento deve ser brusco e preciso, e ao enviar a energia o integrante deve olhar somente para os olhos daquele que vai receber. Enquanto envia, deve gritar RA (tudo ao mesmo tempo - friccionar, enviar, gritar e olhar). A energia assim vai passar por todos os integrantes e o moderador vai polindo os movimentos (força nas mãos, postura, voz firme, olhares profundos, silencio). Quanto mais concentrados mais rápido circula a energia e mais conexão se produz. O movimento 2, REI, que se usa dobrando levemente os joelhos e os braços e fechando os punhos na direção do peito, faz com que o RA seja bloqueado e volte pelo lado oposto (anti-horário). Cada integrante pode usar apenas um REI durante o jogo. E o movimento 3, DANCE, desafia a concentração porque inclui o elemento ridículo de movimento corporal aleatório com um som qualquer agregado. Cada integrante tem direito a usar apenas um DANCE, alongando seu corpo, projetando-o para frente com uma passada grande e esticando o braço apontando para alguém do outro lado do círculo. Este, que recebeu o DANCE, deve vir até o centro do círculo, fazer sua performance pessoal e todos devem acompanhá-lo em seguida repetindo juntos o mesmo movimento. 
iniciativa educativa e social que adentrava os muros. Também contavam com trabalho psicológico e médico semanalmente. Um projeto de empreendimentos e uma mini padaria. Muitos deles faziam artesanato com pintura em vasos e monigotes ${ }^{25}$. Isso justificava o comportamento de aceitação momentânea daquele espaço. "Claro que eu quero sair daqui, mas tenho medo do que podem me fazer ali na rua." 26

Essa dualidade problemática que enfrentavam se notava na cara de preocupação daqueles que se preparavam para sair, inclusive, durante a execução deste projeto, dois deles vivenciaram esta situação. Igualmente outros dois novos integrantes também chegaram, acuados, perdidos, oprimidos. Sentimentos confusos entre o reclamar e agradecer das situações da vida.

Sobre agradecer, justamente foi unânime a relação com a palavra 'vida' . Importante parênteses se faz necessário para refletir aqui sobre esse querer viver, sentir-se vivo, muito independente das inúmeras situações que levaram o jovem a ser infrator. Não vem ao caso explorar o tema, mas num trabalho de educação como este, julgar não tem espaço. Eu apenas observava, e seguia aprendendo.

Nesse contexto apresentei a eles o jogo do RA, como metáfora das energias que se quer livrar, entregar, enviar (problemas) e das energias renovadoras que se quer receber (agradecer). No jogo, a analogia do se livrar e receber foi bem representado no tônus muscular e na rigidez do maxilar. A expectativa de receber igualmente era justificada no sorriso e no olhar atento. O que não durou muito tempo, pois incluir o elemento ridículo chamou mais atenção que qualquer outra coisa a ponto de esquecerem o tempo e se entregarem à empatia. A atenção estava na tensão do: 'será que eu sou o próximo no DANCE?'.

Dos 14 jovens, apenas um deles se negou a jogar e justamente por uma situação inusitada. Durante a dinâmica, realizada no meio da quadra esportiva, percebemos que de um prédio vizinho alguns meninos observavam o trabalho.

\footnotetext{
${ }^{25}$ Monigotes são bonecos, que representam o ano que está terminando, feito com roupas velhas, papelão ou papel mache é recheado com palha ou serragem e muitas vezes ganha fogos de artifício, para ser queimado à meia-noite do dia 31 de dezembro.

${ }^{26}$ Depoimento de um interno extraído de uma fala em meio a uma das dinâmicas.
} 
Escutava-se na voz deles os mesmos comandos (RA - REY e DANCE), igualmente acompanhados de risadas correspondentes a dos internos depois de uma performance. Um dos jogadores se sentiu muito ofendido e se retirou. Os demais observaram, mas não se moveram, queriam seguir jogando. E o fizeram, inclusive com os novatos: um jovem de 16 anos muito bem humorado e uma criança de 12 anos, cuja alegria daquele momento ajudava a secar as lágrimas que insistiam em cair quando, pela primeira vez, justamente naquela tarde, foi por mim, apresentado ao grupo 27 .

Sobre a função do jogo teatral e do valor da sua partilha, para criar novas memórias e ressignificar opressões, insisto em citar Boal quando ele diz que o teatro é uma atividade construída na interatividade coletiva, tendo na aprendizagem mútua um dos fatores mais relevantes já que "descobrindo o teatro, o ser se descobre humano." (Boal, 2005, p. 22).

Enquanto observava o desenrolar da proposta, não conseguia deixar de conjecturar aquela situação interessante em que o privado de liberdade estava, por alguns momentos, mais livre do que o observador externo. Em pleno uso de suas liberdades, naquele momento presente, aqueles meninos do edifício ao lado estavam presos no jogo e compartilhavam do prazer, mesmo de fora, mesmo de longe, sem poder usufruir da mesma maneira a liberdade condicionada dos integrantes do jogo.

Aquecimentos, quase sempre bem recebidos, surtiram como ante sala das emoções no jogo teatral. Digo quase sempre porque raramente repetia estas atividades e tudo que era novo causava uma certa tensão. Fixar o olhar foi um grande avanço, parte do conjunto somático conjugando coluna vertebral, tórax e pescoço, mas, se percebia que o chacra ${ }^{28}$ central sempre estava inconscientemente protegido. Qualquer sinal de aproximação do outro, seja por seu corpo ou olhar, braços e mãos eram acionados em direção ao peito, como que

${ }^{27}$ Relevante comentar que tal interno estava em situação de isolamento por causa da emergência sanitária do Covid-19. E desde que chegara não havia sido apresentado a seus companheiros.

${ }^{28}$ Chacra é uma expressão que caracteriza os centros energéticos de um indivíduo. Em Quéchua, idioma indígena latino, significa terreno de extensão reduzida destinado al cultivo. RAE (2020). 
se fechando, performance natural complementada pelo baixar da fronte. Em todos os jogos, mesmo os já conhecidos, foi necessário um comando insistente: 'soltem os braços, levantem a cabeça, sustentem o olhar'. Por isso o teatro, "no sentido da libertação dos oprimidos, é ação em si mesmo, e é preparação para ações futuras, porque não basta interpretar a realidade: é necessário transformá-la!" (Boal, 2012, p.19).

\section{Querido diário... Ser ou não ser?}

Diante da imensidão dos universos que cruzavam o meu caminho, transformar uma realidade se tornava fútil pretensão, pelo prazo curto de um trabalho de três meses. Então coincidi que todo esforço seria direcionado para um semear. Percebi que estava apenas lavrando o terreno. Às vésperas de terminar o começo do que eu pensava que seria um trabalho completo, como última atividade dessa fase inicial inaugurei um experimento estético.

A ideia era sentir na prática a eficácia da estética do oprimido na construção de uma proposta teatral. Convidei os alunos a criarem coletivamente uma obra de teatro. Todos aceitaram. Primeira pergunta: que história vamos representar, professora? Primeira resposta: Hamlet, de Shakespeare. Entreguei um fragmento 29 e a folhinha de papel oscilava entre uma mão meio trémula e outra desinteressada. Neste exato momento, descobri que dois dos internos eram analfabetos. Esse fato foi ocultado no trabalho com os diários porque eu nunca estabeleci a escrita como única linguagem. Muitos, inclusive os que tinham domínio da língua escrita, só desenhavam. Então, para combinar com o tema a situação toda era para nós, também, uma tragédia. Impossível não perceber no olhar de alguns deles um misto de vergonha e frustração diante da falta daquela habilidade.

Segui. Coração na mão, sensibilizada pelo momento. Mas convicta de que precisaria passar por esta etapa para testar a eficiência da metodologia que aportaria a um verdadeiro propósito. Depois de ler para eles todo o monólogo, pedi

${ }^{29}$ Extrato de "Ser ou não ser, eis a questão." (Shakespeare, 1912, p.56). 
que cada um escolhesse apenas um parágrafo. Os dois minutos que tinham para ler se tornaram um espaço de tempo longínquo, rompido por uma reação ainda mais repugnante quando escutaram que com tal parágrafo realizariam uma tarefa: memorizar para declamar na semana seguinte. Os que não dominavam a escrita deveriam escutar a leitura de um companheiro e tentar adaptar o melhor possível pela sua memória.

Setes dias se passaram e os resultados da experiência estavam nítidos já na recepção: um compreensível desequilíbrio desanimador. Entre os desinteressados e agitados se destacavam os preocupados que escondiam a folhinha de Hamlet na mão. Alguns jogavam bola. Outros dois seguiam em conflito, consequência de uma aula anterior na oficina de padaria, propícia a extrapolar a discussão. Atitudes até então desconhecidas porque em todas as aulas de teatro, até aquele momento, ou os internos me esperavam escutando música, ou vinham ao meu encontro na porta de entrada do pátio interior. Igualmente complicado foi convencê-los a entrar na sala e escutarem a proposta que eu tinha para o dia. Ao fazê-lo, dois deles assumiram "não fizemos a tarefa, professora", baixando a cabeça à espera de uma reprovação. Aquele texto de Shakespeare que poderia ser deleite nas mãos de alguns alunos de teatro era, naquele momento, ameaça de todo um esforço construído.

A experiência foi muito bem sucedida, porque o que eu pretendia com tal dinâmica era testar o quão eficiente é o mecanismo ASCESE da técnica do T.O., que propõe “a necessária subida investigativa do micro, o caso particular, até o macro, o contexto social, onde o caso particular precisa ser entendido dentro do contexto que o insere e o circunda para alcançar uma compreensão ampla". (Santos, p. 87, 2020).

Concordei que o texto de Hamlet não serviu para este propósito porque não correspondeu com a pressa que eu tinha do envolvimento deles em uma dramaturgia. O príncipe da Dinamarca, ainda que tivesse conflitos existenciais parecidos com os conflitos a nível micro de cada integrante do grupo, no macro não encontraria razão de existir porque o contexto é outro. 
Desta forma acessar o contexto no trabalho de envolvimento artístico não poderia ser efetivo se partisse de algo fora da realidade dos envolvidos, como inaugurar a vida teatral de recém apresentados ao mundo cênico, com um Hamlet, impedindo que "a representação do real permitisse a percepção de outras perspectivas sobre a realidade." (Santos, p. 87, 2020).

Desta forma, a didática elegida deveria seguir igualmente os propósitos de Paulo Freire, trabalhar a partir da realidade das pessoas envolvidas. E conduzir deveria partir de um contexto, que não poderia ser outro que não fosse o real, já que "o educador tem que ser um inventor e um constante reinventor de todos esses meios e formas que facilitam cada vez mais a problematização do objeto a ser descoberto e finalmente apreendido pelos aprendizes." (Freire, 1977, p. 18).

Assim entrei com a contra proposta. Diante do texto estética e contextualmente distante daquela realidade, aplicou-se o que propõe Barbara Santos (2019) "uma técnica reflexiva e de introspecção focada na percepção interna que se baseia na capacidade de estar ciente de seus próprios estados subjetivos", desafiando os alunos a problematizarem o tema em si e recriarem suas versões de Hamlet.

Quantos príncipes existem encarcerados em suas próprias dúvidas infinitas e existenciais? Quem eram esses príncipes? E quais eram seus conflitos no teatro da vida? Ao expor a intenção, provocada a propósito ao grupo, automaticamente as feições se relaxaram. Com muita delicadeza, dobrei e guardei o texto do príncipe dinamarquês, ação acompanhada de um silêncio apaziguante entre os jovens, quebrado pela minha fala quando sentenciei: "Este texto é de Shakespeare, um grande escritor, que viveu em outro período e em outro lugar muito distante daqui. Seu príncipe tem um conflito existencial. Até aqui usaremos esta história. Vamos escrever uma história também. Quem será nosso personagem? Que conflito viverá?”.

Impactante mudança recuperou o clima de confiança. Suficiente o bastante para que as duas agentes penitenciárias que acompanhavam o processo deixassem o grupo a sós comigo. Muitos olhares brilharam e colunas se ajustaram 
às cadeiras dispostas em círculo. Alguns corpos tomaram outra forma como que se preparando para uma ação mental. Agora sim, as coisas pareciam fazer sentido.

Com uma folha em branco e uma caneta na mão desempenhava uma nova função: escrivã de contos teatrais. Enquanto eles falavam, todos ao mesmo tempo, tentava organizar as ideias numa linha do tempo e nada mais. Iniciou-se uma discussão muito proveitosa, dos jovens presentes apenas dois se mantiveram mais quietos, o restante brigava por um espaço verbal para dizer sua ideia. A mediação neste momento foi super importante para aproveitar um pouco de cada um de fazê-los sentirem-se importantes e responsáveis pelo processo.

A tentativa de uma dramaturgia saia da cabeça deles, das suas experiências, vivencias, realidades. bombardeada de muitas ideias: "nosso personagem será um príncipe de Dubay"; "não pode ser príncipe porque ninguém é rico aqui”; "pode ser príncipe sim, porque pode ser filho de Deus e ele é o rei"; "então vamos chamar de o príncipe de Deus"; "mas ele vai superar o problema dele, ele vai lutar, então ele deveria ser um guerreiro", "então vamos chamar de guerreiro de Deus"; "ele podia ser reconhecido só como guerreiro, como se fosse um apelido"; "e como ele vai sair daqui poderia ser o guerreiro da liberdade".

Passada a saga da escolha do protagonista, voltei a atenção para o conflito principal, o que provocou outro embate: "Que conflitos existenciais vão viver o guerreiro da liberdade?", perguntei. Um dos jovens, agora escritor, replica na defensiva: "não pode ser sobre a nossa vida, ninguém vai querer falar do seu passado".

A partir da história de vida de cada um, recriar um ser ou não ser; estar ou não estar; sentir ou não sentir somente compactuaria com a ideia central do T.O. se respeitasse o limite imposto em relação à situação particular de cada um, entrando no contexto remetendo aos fatores sociais que construíram a situação em questão. Assim, os sucessos da obra, que deveriam arquitetar, desdobrar e justificar o conflito existencial do "guerreiro da liberdade", poderiam demonstrar um cotidiano que se repete na vida de muitos daqueles indivíduos, mas não de um específico. 
Ou seja, a resposta dada ao jovem dramaturgo foi: "tudo bem, não vamos falar da vida pessoal de ninguém, não se preocupem, vamos focar nos problemas sociais, problemas que afetariam a existência de uma pessoa que vive aqui na nossa cidade, no nosso bairro, na nossa rua talvez...”.

Foi contrastante a atenção dada ao novo material em relação à aula anterior. Agora, o que seria utilizado para construir a cena já não dependia de palavras difíceis escritas numa folha de papel sobre a vida de um personagem escrito por um inglês. Era uma versão da própria vida de cada um deles, porém, desde a perspectiva macro, do social, não do sujeito isolado.

E assim, como dizia Boal (2012, p.25): "tomando consciência de sua autonomia diante dos acontecimentos do cotidiano, caminhando em direção à sua verdadeira liberdade de ação" os criadores de "o guerreiro da liberdade" construíram um esqueleto da estrutura dramatúrgica do que virá a ser sua primeira obra de teatro.

Em resumo, a história criada fala de um jovem, filho de uma mãe solteira que teve que se prostituir para sustentar o filho. Ele cresceu sonhando com a imagem do pai ausente. Ao saber do abandono paterno, revoltou-se contra sua progenitora e saiu de casa. Sem ter como sustentar-se, com a companhia de más influências, começa a roubar para sustentar o vício das drogas. Apaixonou-se por uma menina muito íntegra. Entregou-se a ela. Decidiu abandonar o crime com um último grande roubo. Foi preso. Descobriu que seria pai. Sofreu muitas opressões na prisão. Recebeu auxílio de diversas partes, uma delas veio da bíblia. Fez uma promessa. Descobriu numa das oficinas um talento para a música. Pagou sua dívida. Ganhou a liberdade. E terminou cantando num concerto, sobe os aplausos de sua mãe, sua esposa, seu filho. Tinha ainda um futuro a sua espera.

Não falaram da vida específica de nenhum deles, mas falaram do contexto que conheciam. Propuseram que o protagonista seria encarcerado, porque se envolveu com roubo, para sustentar as drogas, que ele usava para anestesiar a vida dolorida e todas as ausências que vivia dentro de casa. Este Hamlet "sofreria os relhos e a irrisão do mundo, o agravo do opressor, a afronta do orgulhoso"3o

30 Extrato de "Ser ou não ser, eis a questão." (Shakespeare, 1912, p. 56). 
para conseguir sua liberdade e tentar uma vida de paz. Ser ou não ser? Sim, ele seria, para depois não ser.

\section{Querido diário, considerações finais de um trabalho que está apenas começando}

Frente ao avance deste trabalho, que não termina aqui, a instituição aceitou um convite para apoiar uma oficina permanente de atividades de ativação artística e cultural baseadas na pedagogia cênica, como meio educativo de recuperação emocional. A proposta se vinculará a um projeto de extensão do curso de Licenciatura em Artes Cênicas da Universidade Técnica Particular de Loja.

Ademais de uma exposição voluntária dos diários, a obra "O guerreiro da liberdade", que se encontra em construção cênica dentro de um processo que inclui metáforas corporais, sonoras e visuais com o próprio grupo, sobre minha orientação, será apresentada no primeiro semestre de 2021. A parte os alunos ganharam uma oficina específica de violão e coro para complementar a parte final do espetáculo, onde "o guerreiro", já em liberdade faz um concerto musical.

Sobre o diário, como recurso introdutório de uma pedagogia para as artes, entendo que serviu como instrumento de resgate da linguagem simbólica visual. Ainda que alguns não soubessem ler e escrever, sabiam desenhar, copiar, pintar, colar. Exploraram imagens, adesivos, fotografias e palavras com grandes significados, como "JUNIOR", nome do filho de um interno, tatuado em toda a extensão do seu braço.

Catalisador de emoções, o diário serviu também como ferramenta terapêutica, refletida no "guerreiro da liberdade" em uma das cenas sugeridas: "professora, escreve aì, que ele escrevia poemas pra sua mãe no seu diário e se arrependia de ter abandonado ela, ele ficava refletindo nas suas atitudes e isso ajudou ele a mudar de opinião".

Sobre o teatro, numa visão holística da pedagogia das artes cênicas, arremato a importância do T.O. para os processos de validação de vida. Se por um lado foi 
expressão estética da arte, por outro foi aparelho político do oprimido porque ofertou um espaço de liberdade dentro da própria privação, enfrentando, ainda que se tenha recebido farto apoio, olhares cuidadosos, censuradores e duvidosos das capacidades adquiridas. Construtor de subjetividades o teatro ensinou a usar observação, seleção, comparação e interpretação ao acionar o mecanismo de criticidade interna, e estendeu inúmeras leituras possíveis aos seus espec-atores, defendendo suas individualidades como sujeitos dentro de uma atividade coletiva.

Afiançando a importância da "oportunidade de se relacionar com o outro que é seu próprio espelho e, então, repensar sua capacidade de compreensão de si e do mundo" (Rodrigues, 2019, p. 25) eu termino analisando este trabalho num repensar da minha própria existência... "ser ou não ser, eis a questão". Escolhi ser, fazer, enfrentar, engolir, assumir e participar da transformação da sociedade, porque "atores todos nós somos, mas cidadão não é aquele que vive em sociedade, é aquele que a transforma"31. Utopia? Não: decisão, amor, responsabilidade e fé na humanidade.

\section{Referências}

BRECHT, Bertolt. Escritos sobre Teatro. (2a edición). Barcelona: Alba Editorial, 2006. BOAL, Augusto. Legislative Theatre. London: Routledge. 1998.

BOAL, Augusto. Hamlet e o filho do padeiro. Memórias imaginadas. Rio de Janeiro: Record, 2000.

BOAL, Augusto. Teatro do oprimido e outras poéticas políticas. 12a edição. Rio de Janeiro: Civilização Brasileira, 2012.

CAC. Centros de privação de liberdade no Equador. Recuperado de https://www.atencionintegral.gob.ec/centros-de-privacion-de-libertad/. Acesso em: 04 nov. 2020.

CASAMENTO, Andrea. [TEDEX]'. (2017, novembro 21). Sair da prisão. [Arquivo de vídeo]. Recuperado de https://www.youtube.com/watch?v=tnJ7YS5x3EM.

${ }^{31}$ Extrato da mensagem do dia Mundial do Teatro, em 2009, ditada por Augusto Boal na UNESCO em Paris (Duarte-Plon, 2018). 
CONCÍliO, Vicente. Teatro e prisão: dilemas da liberdade artística. Pedagogia do Teatro. Florianópolis: HUCITEC, Aderaldo \& Rothschild, 2008.

FEDES. (04 de novembro de 2020). Fundação para o desenvolvimento. Recuperado de https://fedes.ec/

DUARTE-PLON, Leneide. (2018). Arquivos de Augusto Boal: deambulações de um tesouro. [Texto em Blog]. Carta Maior, o portal da esquerda. Recuperado de https://www.cartamaior.com.br/?/Editoria/Arte/Arquivos-de-Augusto-Boaldeambulacoes-de-um-tesouro/39/39614. Acesso em: 08 out. 2020.

ESPINOSA, Baruch. Ética. Belo Horizonte: Autêntica, 2008.

FREIRE, Paulo. Cartas para a Guiné-Bissau. Notas de uma experiência pedagógica em processo. Buenos Aires: Siglo XXI, 1978.

GAVIRIA, Juan Pablo. (2020) Gera uma mudança em tua vida e encontra teu propósito. [Texto em Blog]. Recuperado de https://www.youtube.com/c/JGaviria/about. Acesso em: 12 out. 2020.

GAVIRIA, Juan Pablo (2020). O que é o medo? [Arquivo de vídeo]. https://www.youtube.com/watch?v=9NiJ5cmwOeg

MCMILLEN, Kim. Quando me amei de verdade. [tradução: Iva Sofia Gonçalves Lima]. Rio de Janeiro: Sextante, 2003.

NUNO, Susana Gómez. (2018). Linguagem e pensamento segundo Piaget e Vygotsky. [Texto em Blog]. Recuperado de https://hypertextuoc.wordpress.com/. Acesso em: 15 out. 2020.

OLIVEIRA, Carmen Silveira de. Sobrevivendo no inferno. A violência juvenil na contemporaneidade. Porto Alegre: Editora Sulina, 2001.

RAE. Significado palavra chacra. Dicionário de língua espanhola. Real Academia espanhola. [Texto em Blog]. Recuperado de https://dle.rae.es/chakra. Acesso em: 12 out 2020.

RODRIGUES, Janilce. Teatro em cadeado: uma experiência em cela de aula. Brasília, DF: 2019.

SANTOS, Bárbara. Teatro do Oprimido, Raízes e Asas: uma teoria da práxis. Rio de Janeiro: Ibis Libris, 2016.

SANTOS, Bárbara. Theatre of the Oppressed ROOTS \& WINGS a theory of praxis. Los Angeles - USA, KURINGA in conjunction with UCLA Art \& Global Health Center.

SANTOS, Bárbara. Kuringa espace for Theatre of the oppressed. Berlin. Alemania. 
[Texto em Blog]. Recuperado de http://kuringa-qualification.org/. Acesso em: 20 jun. 2020.

SHAKESPEARE, William. Hamlet, príncipe de Dinamarca. (Pompeyo Gener, trad.). Madrid: Félix Costa, 1912.

SESI, Departamento Regional da Bahia. Teatro-Fórum e pedagogia da intervenção na indústria. Sistema FIEB. Bahia, 2012.

TAGU, Amélie. Na prisão, o teatro para escapar. Entrevista concedida a Amélie Tagu. Cafébabel. França. [Texto em Blog]. Recuperado de https://cafebabel.com/fr/article/en-prison-le-theatre-pour-sevader5cf675b4f723b378c3a2bbb6/. Acesso em: 28 ago. 2020.

UCLA. Programa de Educação Prisional. (09 de novembro de 2020). Disponível como um e-book. Recuperado de https://prisoneduprogram.ucla.edu/

UNESCO. Declaração de Hamburgo. Quinta conferência Internacional sobre educação de jovens e adultos. UNESCO, 1997.

UTPL. O que somos. Recuperado de https://www.utpl.edu.ec/es/acercade. Acesso em: 09 nov. 2020.

VIOLANTE, Maria Lúcia Vieira. O dilema do decente malandro. São Paulo: CortezAutores Associados, 1982.

Recebido em: 12/10/2020

Aprovado em: 17/11/2020 